\title{
Effect of Scots Pine Sawdust Amendment on Abundance and Diversity of Culturable Fungi in Soil
}

\author{
Monika Małecka ${ }^{1}$, Hanna Kwaśna ${ }^{2 *}$ \\ ${ }^{1}$ Forest Research Institute, Department of Forest Protection, \\ Sękocin Stary, Braci Leśnej 3, 05-090 Raszyn, Poland \\ ${ }^{2}$ Department of Forest Pathology, Poznan University of Life Sciences, \\ Wojska Polskiego 71c, 60-625 Poznan, Poland \\ Received: August 10, 2015 \\ Accepted: September 30, 2015
}

\begin{abstract}
Scots pine and birch were planted in soils left fallow for 3, 6, or 15 years after arable cropping. We investigated the effects of Scots pine sawdust amendment, applied a year before planting, on the abundance and diversity of culturable soil fungi 4, 14, and 16 years after treatment. The treatment was intended to increase populations of fungi antagonistic to Heterobasidion and soil suppressiveness to tree root pathogens. Effects of treatment on fungal abundance were inconsistent; general or local, seasonal or continuous decreases or increases, often significant, were observed. There were, however, significant and continuous increases in frequency of antagonistic Clonostachys + Trichoderma and the mycorrhizal fungus Oidiodendron in treated soils compared with the control in all three fallow areas. Local and seasonal decreases in frequency of Penicillium + Talaromyces, Pseudogymnoascus, and entomopathogenic and nematophagous species were observed in treated soils. Abundance of fungi was moderately and negatively correlated with soil $\mathrm{pH}\left(\mathrm{R}^{2}=-0.61, \mathrm{P}<0.0001\right)$. Abundance of Clonostachys + Trichoderma was moderately and positively correlated with mean annual temperature and positively correlated with total annual rainfall. Fresh sawdust, even applied undecomposed and without added mineral N (to aid microbial decomposition and plant growth), may be beneficial in sandy soil.
\end{abstract}

Keywords: Heterobasidion, Oidiodendron, organic matter, soil fungi, Trichoderma

\section{Introduction}

In 2002 the National Program for the Augmentation of Forest Cover in Poland was revised. The Program anticipates afforestation of 1.5 million ha of marginal land (including post-agricultural and fallow land) and an increase in forest cover to $30 \%$ by 2020 and $33 \%$ by 2050 . Considering soil and weather conditions, this marginal land is being planted with Scots pine (Pinus sylvestris L.), which is the dominant forest tree species in Poland (71\%).

*e-mail: kwasna@up.poznan.pl
Heterobasidion species are considered to be the most economically important conifer forest pathogens in the northern hemisphere $[1,2]$. Scots pine becomes seriously damaged by Heterobasidion annosum (Fr.) Bref. [3]. The fungus spreads through aerial basidiospores to stump surfaces and wounds, and by mycelia via root contacts from tree to tree. It causes root and butt rot, growth loss, and mortality of trees. In favourable conditions seedlings can become infected very soon after planting. In Europe and the USA Heterobasidion is responsible for the loss of \$1.5-2 billion annually. 
Damage is generally greater in the first or second generations of trees grown on post-agricultural or fallow land, which has the least organic matter; a deficiency in nitrogen, potassium, phosphorus, and magnesium; higher $\mathrm{pH}$; increased soil compaction below the plough level; and poor capillarity for water [4]. The shortage of lignified tissues and a specific carbon and energy source for microbiota creates an unfavourable microbiological habitat and causes deficiency of microorganisms that are potentially competitive and antagonistic toward $H$. annosum and helpful in forest site-forming processes.

The aim of our study was to evaluate the abundance, diversity, and temporal and spatial distribution of culturable fungi in soils left fallow for different lengths of time, then amended with fresh Scots pine sawdust. The hypothesis was that the organic matter amendment would change the physical and chemical properties of the soil, which would in turn initiate and stimulate microbiological shifts that would increase the population of fungal antagonists of Heterobasidion and suppressiveness of soil to root pathogens. Studies made 4, 14, and 16 years after treatment were intended to show the temporal dynamics and diversity of microorganisms.

This study is part of a larger project on development and promotion of non-chemical methods of pest management as part of an integrated pest management strategy.

\section{Material and Methods}

\section{Site Description, Treatments, and Sampling}

The experiment was established in three areas (each $300 \mathrm{~m}^{2}, 1 \mathrm{~km}$ apart), that had been left fallow for 3, 6, and 15 years in Głęboki Bród Forest District in northeast Poland (geographic coordinates 53.983333, 23.3). In October 1995, four treatment plots and four control plots (each $25 \mathrm{~m}^{2}$ ) were designated at the four corners of each area. The first soil samples were collected in October 1995; six soil cores (400 g each) were taken from each corner of each plot. The upper and lower $5 \mathrm{~cm}$ of each core were discarded and the central $10 \mathrm{~cm}$ retained, bulked, and mixed by rotating for $24 \mathrm{~h}$. The soil was afterward stored at $4^{\circ} \mathrm{C}$ for 24 hours. Two days after sampling the soil was subjected to chemical and mycological analyses. One day after sampling, a 5-cmthick layer $\left(9 \mathrm{~kg} \cdot \mathrm{m}^{-2}\right)$ of fresh Scots pine sawdust was spread onto the treatment plots. All treatment plots and nontreated control plots were next ploughed to a depth of $35 \mathrm{~cm}$. In spring 1996 the soil was again ploughed and harrowed. Scots pine and birch seedlings were then planted in all plots (one plant per $1 \mathrm{~m}^{2}$ ). (The sawdust was fresh and non-composted and came from tree cutting that took place in 1995.)

Further soil samples were collected 4, 14, and 16 years later (in October 1999, 2009, and 2011) and subjected to the same chemical and mycological analyses that were carried out by the same employees as in 1995 .

The soils left under fallow for 3 and 6 years were defined as sand (sand $89-91 \%$, clay $4-7 \%$, silt $4 \%$ ). The soil left under fallow for 15 years was sandy clay loam (sand $77 \%$, clay $13 \%$, silt $10 \%$ ). The soils were analysed chemically at the Forest Research Institute in Sękocin Stary. $\mathrm{KCl}$ was analysed with a potentiometer according to norm PNISO 103390:1997. Organic carbon was analysed according to norm PN-ISO 10694, total nitrogen according to norm PN-13878, extractable phosphorus with the Egner-Riehm method, and extractable potassium, magnesium, calcium, and sodium according to procedure PB-05 ed. 2 . The soil $\mathrm{pH}$ in $\mathrm{H}_{2} \mathrm{O}$ was 4.4-7.0, organic carbon was $0.87-2.39 \%$, and total nitrogen content was $0.059-0.1 \%$ (Table 1). Mean seasonal and annual temperatures in Głęboki Bród in 1999, 2009, and 2011 were higher than in 1995 and higher (by 4-26\%) than the average (Table 2). Total seasonal and annual rainfall was similar to the average.

\section{Isolation and Identification of Fungi}

The classical soil-dilution method was applied for qualitative and quantitative analyses of fungal communities in 1995 (when nucleic acid sequencing was not easily accessible), and 4, 14, and 16 years later (for direct comparison with results from 1995). The affiliation, activity, and microbiological interactions of many culturable soil fungi are already known and can be used for evaluation of the possible microbiological status of soil (i.e., comparing soil qualities and properties).

A subsample (1 $\mathrm{g}$ ) of soil from each treatment was diluted in $149 \mathrm{~g}$ of sterile quartz sand in a flask, in a safety cabinet. Three replicates (= three flasks) of soil-sand mixture were prepared for each treatment and each control. A subsample $(0.26 \mathrm{mg})$ of the soil-sand mixture was put into a Petri dish and covered with liquid $\left(50^{\circ} \mathrm{C}\right)$ Johnson-Martin's agar (JMA). Thirty replicates were made from the three flasks for each treatment and each control. All plates were incubated for 20 days at $25^{\circ} \mathrm{C}$. All colonies on each plate were examined macro- and microscopically and distinguished on the basis of color, growth rate, hyphal characteristics, and sporulation. Colonies of each species were counted and representatives of fungi were identified by morphotyping on potato dextrose agar (PDA) and synthetic nutrient agar (SNA). Aspergillus and Penicillium species were identified on Czapek yeast autolysate agar (CYA) and $2 \%$ malt extract agar (MEA). Identification was made using mycological keys [5-8].

Abundance of fungi was defined as the number of colony forming units (cfu) in a sample. Frequency of an individual species or group of species was defined as proportion (\%) of isolates in the total number of isolates. Diversity was defined as the number of species in a sample. A species, or group of related species of fungi, was considered as:

i) eudominant, with frequency $>10 \%$

ii) dominant, with frequency $5-10 \%$

iii) subdominant, with frequency $2-5 \%$

iv) recedent, with frequency $1-2 \%$

v) subrecedent, with frequency $<1 \%$ (in at least one treatment).

Fungi in the main dominance class were often grouped on the basis of their morphology and taxonomy. 


\begin{tabular}{|c|c|c|c|c|c|c|c|c|c|c|c|c|c|c|c|c|c|c|c|}
\hline \multirow{5}{*}{ 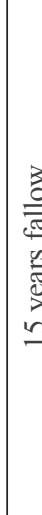 } & \multirow{2}{*}{\multicolumn{2}{|c|}{$\vec{\nabla}$}} & \multirow[t]{2}{*}{ u } & \multirow{2}{*}{$\begin{array}{l}F \dot{\sigma} \\
F\end{array}$} & & \multirow[b]{2}{*}{9} & & \multirow[b]{2}{*}{ ले } & & \multirow{2}{*}{ 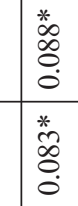 } & \multirow{2}{*}{ 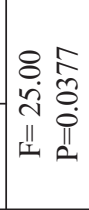 } & \multirow{2}{*}{ 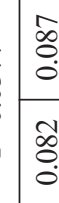 } & \multirow{2}{*}{ 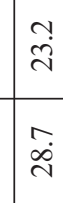 } & \multirow{2}{*}{$\begin{array}{l}m \\
\ddot{n}\end{array}$} & \multirow{2}{*}{\begin{tabular}{|l}
$\vec{i}$ \\
$\vec{r}$
\end{tabular}} & \multirow{2}{*}{$\begin{array}{l}3 \\
\vdots \\
\tilde{\sigma}\end{array}$} & \multirow{2}{*}{$\begin{array}{l}\hat{\sigma} \\
0 \\
\stackrel{0}{0}\end{array}$} & \multirow[t]{2}{*}{ 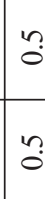 } & \\
\hline & & & & & & & & & & & & & & & & & & & \\
\hline & & & 0 & $\stackrel{*}{\stackrel{*}{\rightleftarrows}}$ & r守 & $\overrightarrow{i n}$ & & $\widehat{\widehat{I}}$ & & 音 & & ôे & $\stackrel{n}{n}$ & $\tilde{n}$ & $\stackrel{t}{\leftrightarrows}$ & $\ddot{0}$ & $\stackrel{m}{ \pm}$ & $\tilde{c}$ & \\
\hline & & ते & ns & 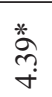 & $\|$ & in & & $\stackrel{\infty}{\infty}$ & & $\overrightarrow{0}$ & & $\overrightarrow{0}$ & $\stackrel{\partial}{\stackrel{\infty}{-}}$ & $\stackrel{\infty}{m}$ & $\stackrel{0}{i}$ & 9 & ले & $\tilde{0}$ & \\
\hline & & $\ddot{g}$ & & $\exists$ & & $\vec{n}$ & & ঙ․ & & $\bar{a}$ & & ò & $\stackrel{\sim}{2}$ & $\exists$ & $\stackrel{\circ}{+}$ & $\stackrel{n}{n}$ & $\begin{array}{l}n \\
n \\
n\end{array}$ & $\because$ & \\
\hline & & $\exists$ & $u$ & $\stackrel{\circ}{+}$ & & F & & 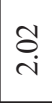 & & $\begin{array}{l}* \\
* \\
\stackrel{0}{\circ} \\
\stackrel{0}{0}\end{array}$ & f. $\begin{array}{l}\infty \\
0 \\
0\end{array}$ & $\begin{array}{l}\hat{\sigma} \\
0 \\
0\end{array}$ & $\stackrel{0}{0}$ & $n$ & $\stackrel{m}{+}$ & 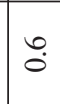 & $\vec{n}$ & $\stackrel{t}{0}$ & \\
\hline & & त & n & $\stackrel{m}{+}$ & & in & & $\stackrel{\tilde{c}}{i}$ & & 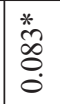 & II & $\begin{array}{l}\text { Õ } \\
\text { Oे. }\end{array}$ & $\stackrel{n}{+}$ & $\hat{\sigma}$ & $\stackrel{m}{+}$ & $\stackrel{1}{=}$ & $\stackrel{\infty}{\oplus}$ & $\stackrel{\nabla}{0}$ & \\
\hline & & 8 & 0 & $\stackrel{*}{\stackrel{*}{+}}$ & ठे & $\overrightarrow{i n}$ & & $\stackrel{\simeq}{=}$ & & $\stackrel{\hat{\sigma}}{0}$ & & 交 & $\stackrel{\sim}{ \pm}$ & $\ddot{n}$ & $\ddot{n}$ & $\exists$ & $\stackrel{0}{\stackrel{2}{\Xi}}$ & $\tilde{c}$ & \\
\hline & & & $n$ & \begin{tabular}{l}
$*$ \\
\multirow{2}{\alpha}{} \\
+ \\
+
\end{tabular} & $\stackrel{0}{1}$ & in & & $\stackrel{?}{\stackrel{2}{2}}$ & & $\begin{array}{l}n \\
\hat{o} \\
0\end{array}$ & & $\begin{array}{l}+ \\
\text { oे } \\
0\end{array}$ & $\begin{array}{l}n \\
\infty \\
\infty\end{array}$ & $\hat{m}$ & $\vec{n}$ & $\ddot{n}$ & חु. & กั & \\
\hline & & ล & 0 & $\stackrel{\sim}{+}$ & & in & & 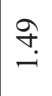 & & $\begin{array}{l}\mathscr{0} \\
\stackrel{0}{0} \\
0\end{array}$ & & $\vec{\infty}$ & $\stackrel{\sim}{\infty}$ & $\tilde{n}$ & $\stackrel{n}{i}$ & $\stackrel{1}{\simeq}$ & $\stackrel{\circ}{\dot{\sim}}$ & $\stackrel{\circ}{-}$ & \\
\hline & & & in & $\stackrel{m}{+}$ & & in & & $\stackrel{\vec{\infty}}{-}$ & & $\begin{array}{l}0 \\
0 \\
0 \\
0\end{array}$ & & $\begin{array}{l}0 \\
\stackrel{0}{0} \\
0\end{array}$ & $\stackrel{\infty}{\vec{\sim}}$ & $\stackrel{\infty}{i}$ & $\vec{n}$ & $\stackrel{\infty}{-}$ & $\frac{\circ}{\dot{m}}$ & $\stackrel{\infty}{0}$ & \\
\hline & & $\ddot{g}$ & & b. & & $\stackrel{0}{r}$ & & $\begin{array}{l}\infty \\
\stackrel{\sigma}{0}\end{array}$ & & $\begin{array}{l}\overrightarrow{5} \\
0 \\
0\end{array}$ & & ?̊? & $\begin{array}{l}\infty \\
\dot{\sim}\end{array}$ & $\stackrel{+}{i}$ & ir & ָ̃ & $\begin{array}{l}n \\
\dot{g} \\
\dot{q}\end{array}$ & $\stackrel{?}{-}$ & \\
\hline & & $\Xi$ & $u$ & $\stackrel{m}{+}$ & $\begin{array}{l}0 \\
10 \\
0\end{array}$ & in & 存: & $\stackrel{n}{-}$ & & 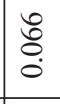 & & $\ddot{0}$ & $\vec{d}$ & $\vec{n}$ & $\ddot{n}$ & $\hat{0}$ & శ్ర & $\stackrel{t}{0}$ & \\
\hline & & & n & $\stackrel{\sim}{i}$ & $\|$ & $\begin{array}{l}\infty \\
\text { in }\end{array}$ & {$\left[\begin{array}{ll}\pi \\
11\end{array}\right.$} & $\stackrel{0}{=}$ & & 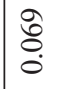 & & $\begin{array}{l}\infty \\
0 \\
0 \\
0\end{array}$ & $\begin{array}{l}\infty \\
\stackrel{0}{0}\end{array}$ & $\stackrel{t}{6}$ & $\mid \stackrel{\infty}{+}$ & 2 & $\overrightarrow{\dot{q}}$ & 3 & \\
\hline & & 8 & 0 & $\begin{array}{l}\stackrel{*}{\sigma} \\
\stackrel{+}{+}\end{array}$ & $\begin{array}{l}\infty \\
\infty \\
\infty\end{array}$ & $\overrightarrow{6}$ & & $\hat{\sigma}$ & & ôे & & \begin{tabular}{l}
$\infty$ \\
\hdashline \\
0 \\
0
\end{tabular} & $\begin{array}{l}\infty \\
\stackrel{\infty}{n}\end{array}$ & $\vec{m}$ & $\vec{F}$ & $\hat{i}$ & in & ?. & \\
\hline & & & ns & $\begin{array}{l}\stackrel{*}{*} \\
\infty \\
+ \\
+\end{array}$ & $\prod_{1}^{0}$ & iे & & $\exists$ & & $\begin{array}{l}\infty \\
\vdots \\
0 \\
0\end{array}$ & & م્ & $\stackrel{\Upsilon}{\Xi}$ & $\hat{n}$ & $\stackrel{\infty}{\infty}$ & $\stackrel{\circ}{i}$ & $\dot{q}$ & $\tilde{m}$ & \\
\hline & & Бे & 0 & 字 & & $\overrightarrow{6}$ & & తి & สิ & \begin{tabular}{l}
$\overline{0}$ \\
\hdashline \\
\end{tabular} & & $\stackrel{8}{\circ}$ & ㅇ. & กี & $\stackrel{+}{i}$ & İ & กี & $\stackrel{0}{-}$ & \\
\hline & & & n & in & & 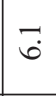 & & $\stackrel{\infty}{\stackrel{\infty}{-}}$ & $\prod_{2}$ & $\ddot{2}$ & & 常 & $\begin{array}{l}\infty \\
\text { in }\end{array}$ & $\tilde{n}$ & $\stackrel{0}{\dot{m}}$ & $\stackrel{i}{0}$ & ì & $\dot{o}$ & \\
\hline & & $\stackrel{8}{0}$ & & $\stackrel{\infty}{m}$ & & $\stackrel{+}{+}$ & & $\begin{array}{l}\infty \\
\infty \\
0\end{array}$ & & 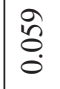 & & $\begin{array}{l}\infty \\
\ddot{0} \\
0 \\
0\end{array}$ & 竎 & $\hat{\varrho}$ & 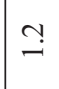 & in & $\begin{array}{l}n \\
\infty \\
\infty\end{array}$ & $n$ & \\
\hline & & 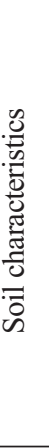 & & $\begin{array}{l}\vec{v} \\
\stackrel{\Xi}{\Xi}\end{array}$ & & 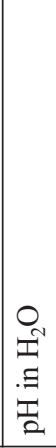 & & 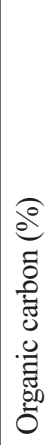 & & 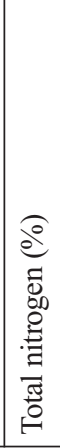 & & 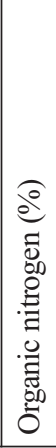 & ن̈ & 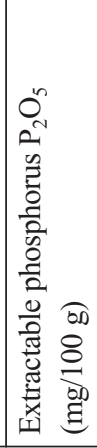 & 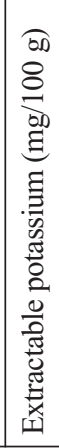 & 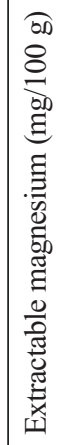 & 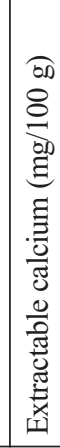 & 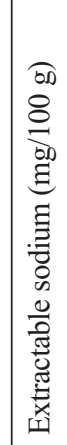 & 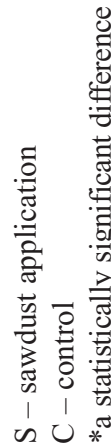 \\
\hline
\end{tabular}




\section{Statistics}

Differences in soil chemical properties were analysed with one-way analysis of variance (ANOVA) using Statgraphics $^{\mathrm{TM}}$ Centurion (Statpoint Technologies, Inc. Warrenton, VA, USA). Abundance and diversity of fungi were analysed with $X^{2}$ test. Diversity within and between fungal communities was compared using diversity indices calculated for each community [9]. Species richness was indicated by the total number of species in the community, Margalef's index (DMg), Shannon's diversity index (H'), and Simpson's diversity index (D). Evenness and dominance were indicated by Shannon's evenness index (E) and Berger-Parker's index (d). Similarity between fungal communities in two systems was determined by calculating the qualitative Sorensen's similarity index (CN). Relationships between soil chemical properties, temperature, rainfall, and abundances of fungi were estimated with Pearson's correlation coefficient.

\section{Results}

\section{Changes in Chemical Properties of Soils after Sawdust Amendment}

In 1995 the soil left fallow for three years had a higher content of extractable phosphorus than the other soils, and the soil left fallow for six years had higher $\mathrm{pH}$ and higher content of extractable potassium, magnesium, and calcium (Table 1). Sawdust amendment usually resulted in slightly higher (usually not significant) $\mathrm{pH}$, percentages of organic carbon and total and organic nitrogen, $\mathrm{C}: \mathrm{N}$ ratio, and content of extractable phosphorus, potassium, magnesium, and calcium than in the control. Large differences between sites in 1995 tended to disappear after four years.

\section{Fungal Community Structure}

Totals of 221 species of fungi and three species of Oomycetes were recorded in the non-rhizosphere soil in all samples (Table 3). Fungi included mostly representatives of Ascomycota. Zygomycota (17 species) were rare and Basidomycota (1 species) occurred sporadically. Seven groups of fungi occurred with frequency $>10 \%$ (eudominants) in at least one treatment. Eudominants, dominants, subdominants, recedents, and subrecedents included 12, 25, 46, 46, and 92 species, respectively.

Effects of sawdust amendment on abundance of fungi were not consistent. Abundances were less (significant or non-significant) in amended than in control plots in soil left fallow for three years (1999 sample) or six years (all samples), and were greater in amended plots in soil left for three years (2009 and 2011 samples) or 15 years (all samples). There was a significant interaction between duration of fallow and year of sample on abundance of fungi $\left(\chi^{2}\right.$ test, $\mathrm{P} \leq 0.001$ or $\mathrm{P} \leq 0.05$ ).
The most common fungi before sawdust amendment included Penicillium adametzii, P. janczewskii, P. jensenii, Pseudogymnoascus roses, and Purpureocillium lilacinum.

Frequencies of Oidiodendron and Trichoderma were greater (usually significantly) after sawdust amendment than in the control. Frequencies of Oidiodendron tended to increase throughout the experiment. Frequencies of Trichoderma tended to decrease after 1999. Trichoderma hamatum and T. harzianum were the most frequent species of Trichoderma. Local or seasonal effects of sawdust amendment on frequencies were observed for Acremonium + Sagenomella spp.; they were significantly more frequent than in controls after three years of fallow in the 1999 sample, and after six years of fallow in the 2011 sample. Frequency of Penicillium + Talaromyces spp. was often significantly less after sawdust amendment throughout the experiment and tended to decrease over time. There were local or seasonal effects of sawdust amendment on frequency of Zygomycota (Absidia + Cunninghamella + Mortierella + Mucor + Umbelopsis spp.); they were significantly less frequent than in controls after six years of fallow in the 2009 and 2011 samples, and after 15 years of fallow in the 2009 sample. Pseudogymnoascus spp. varied between samples and was sometimes less frequent after sawdust amendment than in the control: after three years of fallow in the 1999 sample, after six years of fallow in the 2009 sample, and after 15 years of fallow in the 2011 sample. Entomopathogenic and nematophagous species were sometimes less frequent after sawdust amendment.

Diversity in the communities (measured as number of species) was often less after sawdust amendment than in controls but by only non-significant amounts. The relatively small number of fungal taxa and the infrequent occurrence of many taxa soon after treatment resulted in relatively small diversity indices based on species richness (DMg) and proportional abundance of species ( $\left.\mathrm{H}^{\prime}\right)$. Generally, the greatest diversity occurred in the 1999 sample and in soil left fallow for three years (Table 4). Diversity decreased over time in soils that had been left fallow for three or 15 years.

Rare dominance of single taxa resulted in higher values for Shannon's evenness index (E) and often lower values for Simpson's dominance index (d). Generally, communities were more evenly distributed than in the control in soil left fallow for three years, in the 2009 sample, and in sawdust-treated plots. Sorensen's qualitative similarity index (CN), when used for comparing fungal communities from treated plots and control in a particular year, showed that most similarity in species composition occurred in soils left fallow for six or 15 years and sampled in 2009.

There was moderate negative correlation between the abundance of fungi and soil $\mathrm{pH}\left(\mathrm{R}^{2}=-0.61, \mathrm{P}<0.0001\right)$, and moderate positive correlation between the abundance of Trichoderma and mean annual temperature $\left(\mathrm{R}^{2}=0.45\right.$, $\mathrm{P}<0.0001)$. Stronger correlation was observed between abundance of Trichoderma and total annual rainfall $\left(\mathrm{R}^{2}=0.85, \mathrm{P}<0.0001\right)$. 
Table 2. Temperature and rainfall at Głęboki Bród.

\begin{tabular}{|c|c|c|c|c|c|c|c|}
\hline & \multirow[t]{2}{*}{1995} & \multicolumn{2}{|c|}{1999} & \multicolumn{2}{|c|}{2009} & \multicolumn{2}{|c|}{2011} \\
\hline & & & $\begin{array}{l}\text { Percent of } \\
\text { average* }\end{array}$ & & $\begin{array}{l}\text { Percent of } \\
\text { average** }\end{array}$ & & $\begin{array}{l}\text { Percent of } \\
\text { average** }\end{array}$ \\
\hline Mean seasonal (IV-X) temperature & $12.9^{\circ} \mathrm{C}$ & $13.4^{\circ} \mathrm{C}$ & 112 & $12.6^{\circ} \mathrm{C}$ & 104 & $13.5^{\circ} \mathrm{C}$ & 112 \\
\hline Mean annual temperature & $6.8^{\circ} \mathrm{C}$ & $7.7^{\circ} \mathrm{C}$ & 126 & $6.8^{\circ} \mathrm{C}$ & 106 & $7.3^{\circ} \mathrm{C}$ & 114 \\
\hline Total seasonal (IV-X) rainfall & $392 \mathrm{~mm}$ & $418 \mathrm{~mm}$ & 100 & $411 \mathrm{~mm}$ & 101 & $461 \mathrm{~mm}$ & 113 \\
\hline Total annual rainfall & $584 \mathrm{~mm}$ & $605 \mathrm{~mm}$ & 101 & $597 \mathrm{~mm}$ & 101 & $589 \mathrm{~mm}$ & 100 \\
\hline Hydrothermal coefficient (K) & 1.4 & 1.63 & 95 & 1.73 & 104 & 1.47 & 88 \\
\hline
\end{tabular}

*1961-90, **1971-2000

\section{Discussion}

Scots pine sawdust has been used to improve forest nursery conditions in the production of containerized or bare-root tree seedlings. Sawdust that had been allowed to age was shown (with delayed nitrogen application) to benefit conifer seedlings [10], possibly favoring the growth of antagonists of soil-borne pathogens. Sawdust applied beneath Scots pine roots was thought to have contributed to better development of the assimilation organs [4]. Sawdust improves the physical properties of soil and decreases the toxicity of some soil chemical contaminants [11].

Many nurseries, particularly those using bare-root propagation, have used pine sawdust with success. However, inappropriate application of sawdust can be dangerous, and effects of sawdust on soil conditions - including chemical and microbiological properties - need to be fully investigated.

The fungi detected in the present studies are the main organic matter decomposers in acidic forest soils. Growthbased measurements have revealed fivefold less bacterial growth and fivefold more fungal growth in acidic forest soils $(\mathrm{pH}=4.5)$ compared to agricultural alkaline soils $(\mathrm{pH}=8.3)$, indicating approximately 25-30-fold greater fungal importance in the former [12]. All fungi detected in the present studies were classified as eudominants, dominants, subdominants, recedents, or subrecedents to indicate the scale of their functional potential.

The study showed that amending fallow soil with sawdust often caused either general or local, and seasonal or long-term decreases in the abundance and diversity of the soil fungi. Since similar decreases were also often observed in the control (only ploughed) plots the inhibiting effect of ploughing itself cannot be excluded. Tillage, including ploughing, disrupts hyphal networks and decreases hyphal viability, fungal reproduction and colonization of plant roots [13-15].

Generally, the decrease in abundance of soil fungi can also result from immobilization of nitrogen. Scots pine sawdust has only $0.2 \%$ nitrogen and a very high $\mathrm{C}: \mathrm{N}$ ratio. Wood decomposers naturally occurring in soil require materials with $1-2 \%$ of nitrogen to proceed with degradation. Finding only $0.2 \%$ in sawdust, they utilize inorganic soil nitrogen. This leads to a shortage of inorganic soil nitrogen and less decomposition of organic residues with high $\mathrm{C}: \mathrm{N}$ ratio, and this is followed consequently by decreased abundance of mycobiota. However, total nitrogen content was only occasionally slightly less in amended soils (left fallow for six or 15 years; 2011 sample) than in the non-amended control, which suggests that $\mathrm{N}$ immobilization was not a main reason for decreased fungal populations after treatment.

Scots pine sawdust has high cellulose (55\%), and less lignin $(30 \%)$ and hemicellulose $(10 \%)$ content. Cellulolysis provides carbohydrates (the breakdown products) shortly after sawdust incorporation into soil. Theoretically, the abundance of carbohydrates should have stimulated the growth and reproduction of microorganisms [16]. However, the communities described here only rarely behaved according to such a scheme. This may be explained by short- or long-term suppression of certain species of fungi by:

i) alkalization of the treated soils

ii) higher concentration of $\mathrm{CO}_{2}$ produced during decomposition of sawdust

iii) toxic compounds present in sawdust or produced during their degradation (i.e., soluble resins, tannins, terpenes, and biologically active phenolic monomers leached from wood particles during the winter)

iv) antibiotics produced by actinomycetes stimulated by sawdust

v) competition by bacteria that are the predominant degraders of lignocellulosic detritus

vi) competition by the dominant fungal species, including Trichoderma.

Trichoderma and Oidiodendron were more abundant in treated soils despite slight alkalization caused by the sawdust amendment. A similar level of alkalization was observed in two soil types, i.e., in sand (left fallow for three or six years) and lightly clayed sand (left fallow for 15 years) despite the greater buffering capacities of clayed soils [17]. The acidity of the soils after treatment was, however, still in the range favoured by Trichoderma ( $\mathrm{pH}$ 5.5-7.50) [18]. The greater abundance of Trichoderma was often associated with smaller populations of Zygomycota and P. roseus. This may be partly because of their poor ability to decompose cellulose and hemicellulose. 


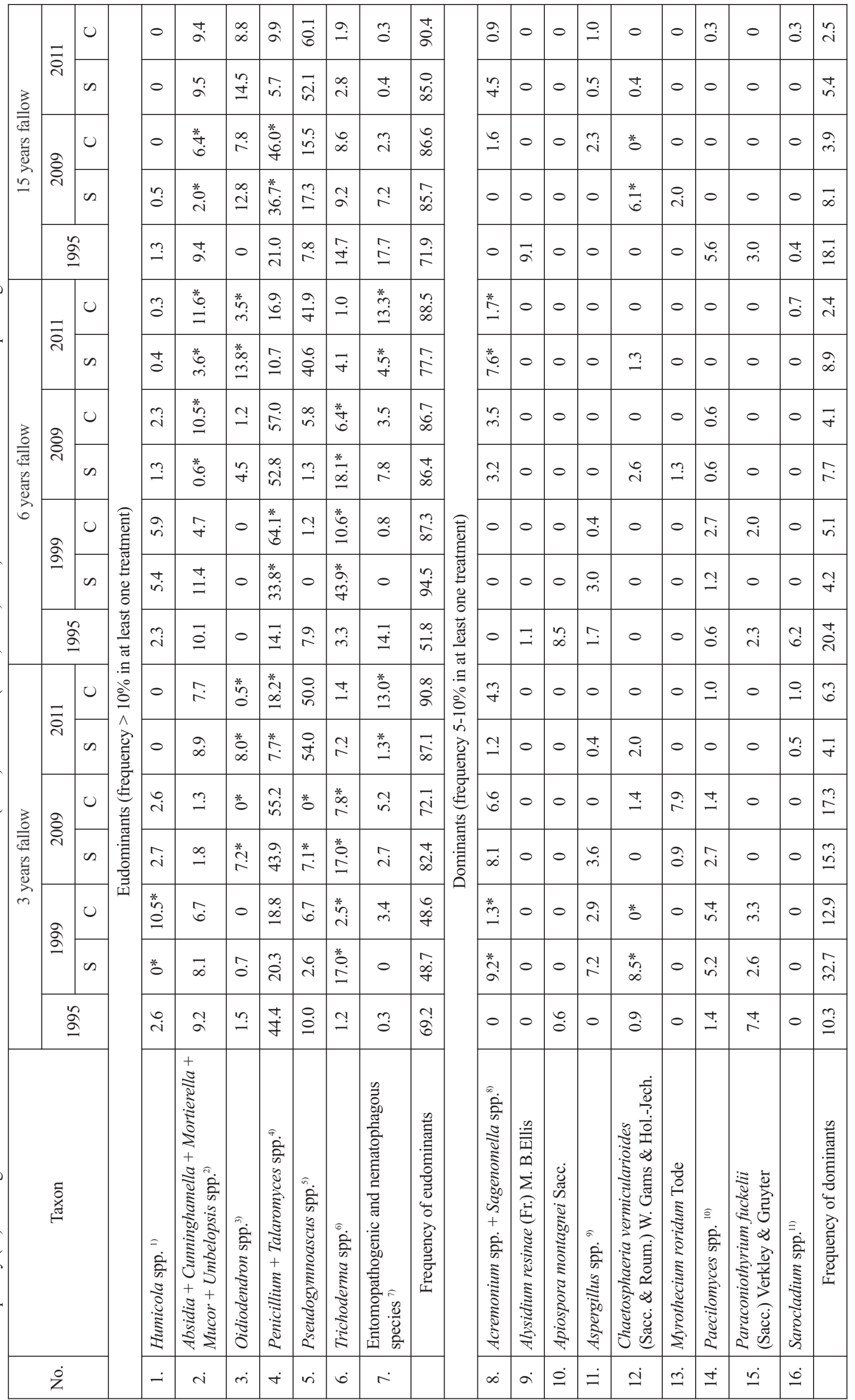




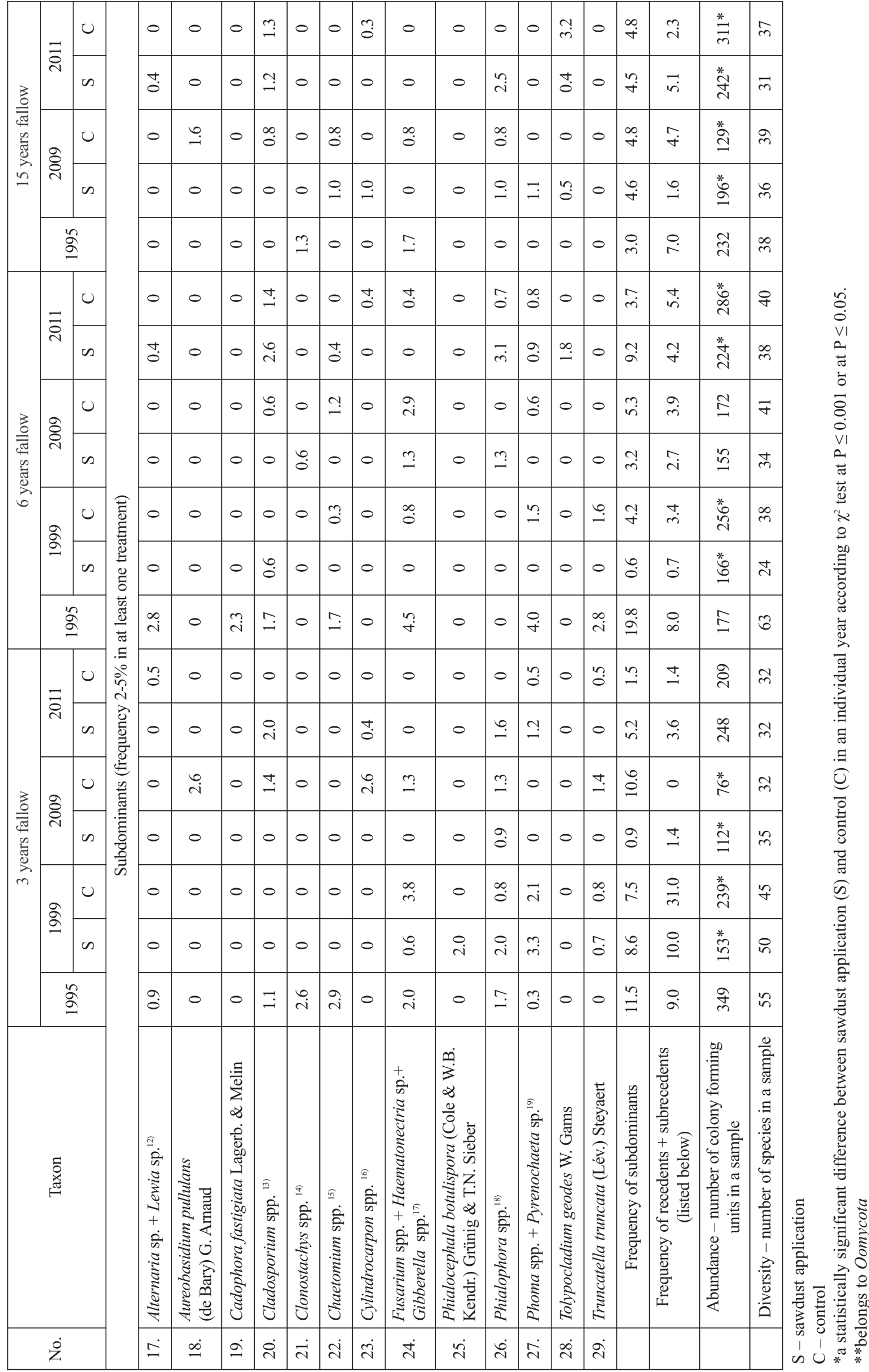


Table 3. Continued.

Explanations:

1) Humicola fuscoatra Traaen $+H$. grisea Traaen

2) Absidia caerulea Bainier, + A. cylindrospora Hagem + A. glauca Hagem + A. spinosa Lendner + Cunninghamella elegans Lendn. + Mortierella alpina Peyronel + M. gamsii Milko + M. hyalina (Harz) W. Gams + M. minutissima van Tieghem + M. parvispora Linnem. + M. pusilla Oudem. + M. verticillata Linnem. + Mortierella spp. + Mucor hiemalis Wehmer + M. moelleri (Vuill.) Lendn. + M. racemosus Fresen. + Umbelopsis nana (Linnem.) Arx + U. vinacea (Dixon-Stew.) Arx

3) Oidiodendron chlamydosporicum Morrall + O. echinulatum G.L. Barron + O. griseum Robak + O. tenuissimum (Peck) S. Hughes $+O$. truncatum G.L. Barron

4) Penicillium adametzii Zaleski + P. aurantiogriseum Dierckx + P. brevicompactum Dierckx $+P$. canescens Sopp. $+P$. chrysogenum Thom $+P$. citrinum Thom $+P$. commune Thom $+P$. corylophilum Dierckx $+P$. daleae Zaleski $+P$. decumbens Thom $+P$. dierckxii Biourge $+P$. digitatum (Pers.) Sacc. $+P$. expansum Link + P. griseofulvum Dierckx + P. herquei Bainier $\&$ Sartory $+P$. janczewskii Zaleski $+P$. jensenii Zaleski + P. lanosum Westling + P. lividum Westling + P. melinii Thom + P. notatum Westl. + P. ochrochloron Biourge + P. paxilli Bainier + P. raistrickii G. Sm. + P. restrictum J.C. Gilman \& E.V. Abbott + P. sacculum E. Dale + P. sclerotiorum J.F.H. Beyma + P. simplicissimum (Oudem.) Thom + P. spinulosum Thom + P. thomii Maire + P. vinaceum Gilman \& Abbott + P. waksmanii Zaleski + Penicillium spp. + Talaromyces flavus (Klöcker) Stolk \& Samson + T. funiculosus (Thom) Samson, N. Yilmaz, Frisvad \& Seifert + T. islandicus (Sopp) Samson, N. Yilmaz, Frisvad \& Seifert + T. minioluteus (Dierckx) Samson, N. Yilmaz, Frisvad \& Seifert + T. pinophilus (Hedgc.) Samson, N. Yilmaz, Frisvad \& Seifert + T. purpureogenus Samson, Yilmaz, Houbraken, Spierenb., Seifert, Peterson, Varga \& Frisvad + T. rugulosus (Thom) Samson, N. Yilmaz, Frisvad \& Seifert + T. variabilis (Sopp.) Samson, N. Yilmaz, Frisvad \& Seifert + T. verruculosus (Peyronel) Samson, N. Yilmaz, Frisvad \& Seifert

5) Pseudogymnoascus pannorum (Link) Minnis \& D.L. Lindner + P. roseus Raiłło

6) Trichoderma aureoviride Rifai $+T$. fertile Bissett $+T$. hamatum (Bonord.) Bainier $+T$. harzianum Rifai $+T$. koningii Oudem. $+T$. longipilis Bissett + T. pseudokoningii Rifai + T. polysporum (Link) Rifai + T. pubescens Bissett + T. strigosum Bissett + T. virens (Mil. Gidd et Fost.) von Arx $+T$. viride Pers. et Fr.

7) Beauveria brongniartii (Sacc.) Petch, + Isaria farinosa (Holmsk.) Fr. + Lecanicillium lecanii (Zimm.) Zare \& W. Gams + L. tenuipes (Petch) Zare \& W. Gams + Metacordyceps chlamydosporia (H.C. Evans) G.H. Sung, J.M. Sung, Hywel-Jones \& Spatafora + Metarhizium anisopliae (Metschnikoff) Sorokin + Pochonia bulbillosa (W. Gams \& Malla) Zare \& W. Gams + Purpureocillium lilacinum (Thom) Luangsa- ard, Houbraken, Hywel-Jones \& Samson Houbraken, Hywel-Jones \& Samson + Simplicillium lamellicola (F.E.V. Sm.) Zare \& W. Gams [5, 6, 24, 25].

8) Acremonium egyptiacum (J.F.H. Beyma) W. Gams + A. larvarum (Petch) W. Gams + A. felinum (Marchal) Kiyuna, K.D. An, Kigawa $\&$ Sugiy $+A$. charticola $($ Lindau) W. Gams + A. fusidioides (Nicot) W. Gams + A. hyalinulum (Sacc.) W. Gams + A. pteridii W. Gams \& J.C. Frankland + A. verruculosum W. Gams \& Veenb.-Rijks + Acremonium spp.+ Sagenomella diversispora (J.F.H. Beyma) W. Gams

9) Aspergillus chevalieri Thom \& Church + A. fumigatus Fresen. + A. repens (Corda) Sacc. + A. ruber Thom \& Church + A. sydowii (Bainier \& Sartory) Thom \& Church + A. versicolor (Vuill.) Tiraboschi

10) Paecilomyces marquandii (Massee) S. Hughes + P. cf. victoriae (Svilv.) A.H.S. Br. \& G. Sm. + P. variotii Bainier

11) Sarocladium glaucum (W. Gams) Summerb. + S. strictum (W. Gams) Summerb.

12) Alternaria alternata (Fr.) Keissler + Lewia infectoria (Fuckel) M.E. Barr \& E.G. Simmons

13) Cladosporium cladosporioides (Fresen.) G.A. de Vries + C. herbarum (Pers.) Link

14) Clonostachys candelabrum (Bonord.) Schroers + C. rosea (Link) Schroers, Samuels, Seifert \& W. Gams

15) Chaetomium funicola Cooke + Ch. homopilatum Omvik + Chaetomium sp.

16) Cylindrocarpon magnusianum Wollenw. + Cylindrocarpon sp.

17) Fusarium flocciferum Corda + F. incarnatum (Desm.) Sacc. + F. merismoides Corda + F. oxysporum Schlecht. + F. redolens Wollenw. + Gibberella avenacea R.J. Cook + G. intricans Wollenw.+ G. pulicaris (Fr.) Sacc. + Haematonectria haematococca (Berk. \& Broome) Samuels \& Rossman

18) Phialophora alba J.F.H. Beyma + Ph. bubakii (Laxa) Schol-Schwarz + P. cyclaminis J.F.H. Beyma

19) Phoma eupyrena Sacc. + Ph. glomerata (Corda) Wollenw. \& Hochapfel + Ph. herbarum Westend. + Ph. pinodella (L.K. Jones) Morgan-Jones \& K.B. Burch + Phoma sp .+ Pyrenochaeta cava (Schulzer) Gruyter, Aveskamp \& Verkley

Recedents (frequency 1-2\% in at least one treatment) - Arthrinium phaeospermum (Corda) M.B.Ellis, Candida albicans (Robin) Berkhout, Chrysosporium merdarium (Link) J.Carm., Ch. pannicola (Corda) v. Oorschot \& Stalpers, Ch. tropicum J.W. Carmich., Chrysosporium sp., Cladorrhinum bulbillosum W. Gams \& Mouch., Epicoccum nigrum Link, Gliomastix roseogrisea (S.B. Saksena) Summerb. Gams, Monodictys putredinis (Wallr.) S. Hughes, Papulaspora equi Shadomy \& Dixon , P. nishigaharana Ts. Watan., Scytalidium japonicum Udagawa.Tominanga \& t Hamaoka, Sporothrix schenckii Hectoen \& C.F. Perkins, Torula sp., Trichocladium asperum Harz .

Subrecedents (frequency $<1 \%$ in at least one treatment) - Ascomycota spp., Basidiomycota sp., Bipolaris sorokiniana (Sacc.) Shoemaker, Boeremia exigua (Desm.) Aveskamp, Gruyter \& Verkley, Cladophialophora chaetospira (Grove) Crous \& Arzanlou, Exophiala mansonii (Castell.) de Hoog, Fusicolla aquaeductuum (Radlk. \& Rabenh.) Gräfenhan, Seifert \& Schroers, Geotrichum candidum Link, Gibellulopsis nigrescens (Pethybr.) Zare, W. Gams \& Summerb., Gilmaniella macrospora Moustafa, Hormonema sp., Hyalodendron sp., Lasiadelphia lasiosphaeriae (W. Gams) Réblová \& W. Gams, Leptosphaeria coniothyrium (Fuckel) Sacc., Mariannaea elegans (Corda) Samson, Memnoniella echinata (Riv.) Galloway, Microdochium bolleyi (Sprague) de Hoog \& Hermanides-Nijhof, Monilia sp., Monocillium mucidum W.Gams, M. nordinii (Bourchier) W.Gams, Mycelium radicis atrovirens Melin, Myrmecridium schulzeri (Sacc.) Arzanlou, W. Gams \& Crous, Parasympodiella clarkii B. Sutton, Periconia macrospinosa Lefebre \& Johnson, Pesotum sp. (anamorph of Ceratocystis sp.), Phytophthora cinnamomi Randsb, P. quercina T. Jungb, Pseudocochliobolus eragrostidis Tsuda \& Ueyama, Pythium sp.**, Scolecobasidium constrictum E.V. Abbott, Setophoma terrestris (H.N. Hansen) Gruyter, Aveskamp \& Verkley, Sphaerodes fimicola (E.C. Hansen) P.F. Cannon \& D. Hawksw., Trichocladium opacum (Corda) S. Hughes, Trichosporiella cerebriformis (de Vries \& Klien-Natrop) Gams, Verticillium nubilum Pethybr., non sporulating - 22 morphologically different cultures. 
Table 4. Diversity indices for fungi from soils left fallow for different durations before (1995) and after (1999, 2009, 2011) sawdust amendment and tree planting.

\begin{tabular}{|c|c|c|c|c|c|c|c|c|c|c|c|c|c|c|c|c|c|c|c|}
\hline \multirow{3}{*}{ Index } & \multicolumn{7}{|c|}{3 years fallow } & \multicolumn{7}{|c|}{6 years fallow } & \multicolumn{5}{|c|}{15 years fallow } \\
\hline & \multirow{2}{*}{ ڤ̆ } & \multicolumn{2}{|c|}{1999} & \multicolumn{2}{|c|}{2009} & \multicolumn{2}{|c|}{2011} & \multirow{2}{*}{ ڤू } & \multicolumn{2}{|c|}{1999} & \multicolumn{2}{|c|}{2009} & \multicolumn{2}{|c|}{2011} & \multirow{2}{*}{$\stackrel{2}{\sigma}$} & \multicolumn{2}{|c|}{2009} & \multicolumn{2}{|c|}{2011} \\
\hline & & $\mathrm{S}$ & $\mathrm{C}$ & $\mathrm{S}$ & $\mathrm{C}$ & $\mathrm{S}$ & $\mathrm{C}$ & & $\mathrm{S}$ & $\mathrm{C}$ & $\mathrm{S}$ & $\mathrm{C}$ & $\mathrm{S}$ & $\mathrm{C}$ & & $\mathrm{S}$ & $\mathrm{C}$ & $\mathrm{S}$ & $\mathrm{C}$ \\
\hline \multicolumn{20}{|c|}{ Species richness indices } \\
\hline Margalef's index (DMg) & 9.22 & 9.74 & 8.03 & 7.20 & 7.15 & 5.62 & 5.80 & 11.97 & 4.49 & 6.67 & 6.54 & 7.77 & 6.83 & 6.89 & 6.79 & 6.63 & 7.81 & 5.46 & 6.27 \\
\hline $\begin{array}{l}\text { Shannon's diversity index } \\
\left(\mathrm{H}^{\prime}\right)\end{array}$ & 3.15 & 3.34 & 2.98 & 3.33 & 3.14 & 2.40 & 2.31 & 3.81 & 2.66 & 2.24 & 3.18 & 3.26 & 2.71 & 2.53 & 3.00 & 3.09 & 3.19 & 2.37 & 2.26 \\
\hline \multicolumn{20}{|c|}{ Evenness or dominance indices } \\
\hline $\begin{array}{l}\text { Shannon's evenness } \\
\text { index (E) }\end{array}$ & 0.78 & 0.85 & 0.78 & 0.93 & 0.90 & 0.69 & 0.66 & 0.92 & 0.83 & 0.61 & 0.90 & 0.88 & 0.74 & 0.68 & 0.82 & 0.86 & 0.87 & 0.69 & 0.62 \\
\hline Simpson’s index (D) & 0.08 & 0.06 & 0.10 & 0.04 & 0.05 & 0.17 & 0.23 & 0.03 & 0.09 & 0.26 & 0.05 & 0.06 & 0.12 & 0.17 & 0.07 & 0.07 & 0.06 & 0.16 & 0.23 \\
\hline Berger-Parker's index (d) & 0.18 & 0.17 & 0.09 & 0.08 & 0.13 & 0.37 & 0.45 & 0.08 & 0.19 & 0.49 & 0.11 & 0.16 & 0.29 & 0.37 & 0.14 & 0.17 & 0.16 & 0.27 & 0.43 \\
\hline $\begin{array}{l}\text { Sorensen qualitative } \\
\text { similarity index }(\mathrm{CN})\end{array}$ & - & \multicolumn{2}{|c|}{0.46} & \multicolumn{2}{|c|}{0.38} & \multicolumn{2}{|c|}{0.40} & - & \multicolumn{2}{|c|}{0.42} & \multicolumn{2}{|c|}{0.48} & \multicolumn{2}{|c|}{0.38} & - & \multicolumn{2}{|c|}{0.53} & \multicolumn{2}{|c|}{0.44} \\
\hline
\end{tabular}

$\mathrm{S}$ - sawdust application

$\mathrm{C}$ - control

Zygomycota are saprotrophs, with the potential to increase plant resistance to phytopathogens, while $P$. roseus is associated with ectomycorrhizae of conifers. These beneficial properties suggest that increased populations in soil would be useful.

The genus Trichoderma includes 89 species [19]. Many species are opportunistic avirulent plant symbionts and these are often considered for development as biocontrol agents against fungal phytopathogens [20]. Trichoderma occurs in soils at all latitudes and stimulation of its populations and activity, by manipulation of the soil environment (by amendment of organic matter), in one habitat may have general relevance.

A few species of Trichoderma detected in our studies (T. harzianum, T. koningii, T. viride) are known to restrict the growth of $H$. annosum in vitro and in vivo [3, 21]. Trichoderma hamatum, eudominant in the present study, is known for its antagonistic properties toward Thanatephorus cucumeris (A. B. Frank) Donk. Possible mechanisms involved in disease control include antibiosis, competition, mycoparasitism, and induction of plant defense responses. Trichoderma harzianum, another eudominant after sawdust amendment, can produce significant amounts of carbon dioxide, ethanol, water-soluble antibiotics and antifungal compounds, and fixed or volatile metabolites that are responsible for antibiosis, including the inhibition of growth and sporulation of some soil fungi.

An increase in Trichoderma populations in treated areas may increase the suppressiveness of soil toward H. annosum. Because of the preference of Trichoderma for higher temperatures $[18,21]$, more successful biocontrol effects may be expected in warmer years or in areas more exposed to solar radiation. Stimulation of growth of Trichoderma by moisture may be necessary in sandy soils, considering that the Trichoderma population size required for suppression was found to be $10^{8}$ conidia $\cdot \mathrm{g}^{-1}$ of soil in dry fine sandy loam and $10^{4}-10^{5}$ conidia. $\mathrm{g}^{-1}$ of soil in moist clay loam. The beneficial effects of rainfall on the development of Trichoderma populations in sandy soils are supported by the correlation between abundance of Trichoderma and annual rainfall in the present study. More rainfall washes out the clay and humus, thus reducing the soil's buffering capacity and increasing its acidification, which would generally stimulate the growth of fungi.

Oidiodendron is another generally beneficial fungus owing to its relationship with plants; some Oidiodendron species are ericoid mycorrhizal fungi. It is considered to be a cosmopolitan genus in soil and in/on cellulose substrates. In the present study, however, it was not always found in some fallow soils. Its population increased slowly (becoming greatest 14-16 years after sawdust treatment), partly as a result of stabilization of soil acidity (the fungus favours soil $\mathrm{pH}=3.0-5.0$ ) [22] and from the presence of Vaccinium on the site.

The application of sawdust did not increase the abundance of another Heterobasidion antagonist: Penicillium adametzii [23].

Since Heterobasidion infects trees continuously over a long period, antagonists are required to have long persistence in the ecosystem without the addition of nutrients or amendments. Increased populations of Trichoderma and Oidiodendron in sawdust-amended soils relative to nontreated controls, even 16 years after treatment, should ensure long-term suppressiveness of root pathogens in sandy soil.

\section{Conclusions}

Fresh sawdust may be beneficial as an amendment to sandy soil, even where applied without exposure to weathering and with no added mineral $\mathrm{N}$ (in quantities sufficient to meet the requirements of both sawdust-decomposing microorganisms and the development of transplanted plants). 


\section{Acknowledgements}

The authors wish to thank the National Forest Holding "State Forests" in Poland for funding part of the study within research project No. BLP-214.

\section{References}

1. OTROSINA W.J., GARBELOTTO M. Heterobasidion occidentale sp. nov. and Heterobasidion irregulare nom. nov.: a disposition of North American Heterobasidion biological species. Fungal Biol. 114, 16, 2010.

2. WORRALL J.J., HARRINGTON T.C., BLODGETT J.T., CONKLIN D.A., FAIRWEATHER M.L. Heterobasidion annosum and $H$. parviporum in the southern Rocky Mountains and adjoining states. Plant Dis. 94, 115, 2010.

3. SIEROTA Z. Heterobasidion root rot in forests on former agricultural lands in Poland: Scale of threat and prevention. Sci Res. Ess. 8, (47), 2298, 2013.

4. TKACZYK M., GUL P., OLEJARSKI I., OSZAKO T. Possibility of using organic fertilization to grow pine plantations on former agricultural lands. Fol. For. Pol. 55, 190, 2013

5. DOMSCH K.H., GAMS W., ANDERSON TRAUTEHEIDI. Compendium of Soil Fungi. Academic Press. London. 1980.

6. SEIFERT K., MORGAN-JONES G., GAMS W., KENDRICK B. The Genera of Hyphomycetes. [CBS Biodiversity Series no. 9] Utrecht: CBS-KNAW Fungal Biodiversity Centre. 2011.

7. KLICH M.A., PITT J.I. A laboratory guide to the common Aspergillus species and their teleomorphs. Commonwealth Scientific and Industrial Research Organization, Division of Food Processing, North Ryde, New South Wales, Australia.1992.

8. PITT J. The genus Penicillium and its teliomorphic states Eupenicillium and Talaromyces. Academic Press, New York. 1979.

9. MAGURRAN A.E. Ecological diversity and its measurement. Princeton University Press, Princeton, NJ, 1988.

10. HILDEBRAND D.M., STONE J.K., JAMES R.L., FRANKEL S.J. Alternatives to preplant soil fumigation for western forest nurseries. USDA Forest Service, Pacific Northwest Research Station. Gen Tech Rep PNW-GTR-608. pp. 1-27, 2004.

11. BELLO D., TRASAR-CEPEDA C., LEIRÓS M.C., GILSOTRES F. Effect of sawdust amendment on mineralization of organic nitrogen in a 2,4,5-trichlorophenol contaminated soil. J. Soil Sci. Plant Nutr. 13, 215, 2013.
12. ROUSK J., BROOKES P.C., BÅ̊TH E. Contrasting soil $\mathrm{pH}$ effects on fungal and bacterial growth suggest functional redundancy in carbon mineralization. Appl. Environ. Microb. 75, 1589, 2009.

13. BORIE F., RUBIO R., ROUANET J.L., MORALES A., BORIE G., ROJAS C. Effects of tillage systems on soil characteristics, glomalin and mycorrhizal propagules in a Chilean Ultisol. Soil Till. Res. 88, 253, 2006.

14. CASTILLO C.G., RUBIO R., ROUANET J.L., BORIE F. Early effects of tillage and crop rotation on arbuscular mycorrhizal fungal propagules in an Ultisol. Biol. Fert. Soils 43, 83, 2006.

15. GOSLING P., HODGE A., GOODLASS G., BENDING G.D. Arbuscular mycorrhizal fungi and organic farming. Agric. Ecos. Environ. 113, 17, 2006.

16. COSTA B.O., NAHAS E. Growth and enzymatic responses of phytopathogenic fungi to glucose in culture media and soil. Braz. J. Microbiol. 43, 332, 2012.

17. NYLE C.B., WEIL R.R. Elements of the Nature and Properties of Soils ( $3^{\text {rd }}$ Ed). Prentice Hall. 2009.

18. SINGH A., SHAHID M., SRIVASTAVA M., PANDEY S., SHARMA A., KUMAR V. Optimal physical parameters for growth of Trichoderma species at varying $\mathrm{pH}$, temperature and agitation. Virol. Mycol. 3, 127. 2014. doi: 10.4172/ 2161-0517.1000127

19. SAMUELS G.J. Trichoderma: systematics, the sexual state, and ecology. Phytopathology 96, 195, 2006.

20. HARMAN G.E. Overview of mechanisms and uses of Trichoderma spp. Phytopathology 96, 190, 2006.

21. NIKOLAJEVA V., PETRINA Z., VULFA L., ALKSNE L., EZE D., GRANTINA L., GAITNIEKS T., LIELPETERE A. Growth and antagonism of Trichoderma spp. and conifer pathogen Heterobasidion annosum s.l. in vitro at different temperatures. Adv. Microbiol. 2, 295, 2012.

22. RICE A.V., CURRAH R.S. Oidiodendron: A survey of the named species and related anamorphs of Myxotrichum. Stud. Mycol. 53, 83, 2005.

23. SZWAJKOWSKA-MICHAŁEK L., KWAŚNA H., ŁAKOMY P., PERKOWSKI J. Inhibition of Armillaria and Heterobasidion growth by Penicillium adametzii isolated from Pinus sylvestris forest soil. For. Path. 42, 454, 2012.

24. SUN B.D., LIU X.Z. Occurrence and diversity of insectassociated fungi in natural soils in China. Appl. Soil Ecol. 39, 100, 2008.

25. QUESADA-MORAGA E., NAVAS-CORTÉS J.A., MARANHAO E.A.A., ORTIZ-URQUIZA A., SANTIAGO-ÁLVAREZ C. Factors affecting the occurrence and distribution of entomopathogenic fungi in natural and cultivated soils. Mycol. Res. 111, 947, 2007. 